\title{
Pannóniai üledékképződés és szerkezeti mozgások az Északi-pikkely (Kelet-Mecsek) területén
}

\author{
Kovács Ádám ${ }^{1}$, Sebe Krisztina ${ }^{2}$, Magyar Imre ${ }^{3}$, Szurominé Korecz Andrea ${ }^{4}$, Kovács Erika ${ }^{5}$
}

1ELTE Általános és Alkalmazott Földtani Tanszék, 1117 Budapest, Pázmány Péter sétány 1/C, (kovacs.adam13@ gmail.com) ${ }^{2}$ PTE Földtani és Meteorológiai Tanszék; 7624, Pécs, Ifjúság útja 6. (sebe @ gamma.ttk.pte.hu)

${ }^{3}$ MTA-MTM-ELTE Paleontológiai Kutatócsoport, 1431 Budapest, Pf. 137. (immagyar@mol.hu)

${ }^{4}$ Mol Nyrt. KTD Kutatási Laboratórium, 1039 Budapest, Szt. István út 14. (kaszuro@mol.hu)

${ }^{5}$ Earth Science Institute, Slovak Academy of Sciences, Banská Bystrica, (kovacs@ savbb.sk)

\section{Upper Miocene sedimentation and tectonics in the Northern Imbricate Zone (Eastern Mecsek Mts, SW Hungary)}

Abstract

The 'Northern Imbricate Zone' along the northern edge of the Eastern Mecsek Mts, SW Hungary, are a complicated, narrow, uplifted band of basement, partly covered by Neogene sediments. The area is heavily deformed, with young, postMiocene tectonic movements. Pannonian (Upper Miocene) lacustrine sediments are most widely distributed around the village of Nagymányok. Through their investigation it is possible to reveal the Late Miocene and subsequent evolution history. The present study concentrates on the temporary outcrops of Lake Pannon deposits created in 2015 south of Nagymányok, accompanied with fossil collection from the individual strata. This $\sim 120 \mathrm{~m}$ thick sedimentary successsion is atypical compared to other parts of the Mecsek Mts, with relatively fine-grained, fossil-rich clays to fine sands above the thin $(<3 \mathrm{~m})$, gravelly base sands of local provenance. The fauna is dominated by bivalves; however, gastropods, ostracods and fish and plant remains have also been found. The base sands belong to the Prosodacnomya dainellii - P. vutskitsi mollusc biozones, the finer sediments to the Congeria rhomboidea biozone.

Through the joint interpretation of the litho- and biofacies the sedimentary environments and the age of deposition of the sediments were identified, while the evolution of the wider surroundings was delineated by adding the tectonic observations, borehole data and seismic sections to the previous information. Lacustrine sedimentation first started only in the northern foreland of the mountains, accummulating offshore marls, claymarls and silts (Szák Claymarl Fm). The time of flooding is unknown in the trough directly at the foot of the mountains due to the lack of wells and palaeontological data; the wide platform north of it became flooded no sooner than 8.9 Ma based on mollusc data. This was followed by the fine sands to clays of the Alpine-Carpathian delta system (Újfalu Fm), approx. 7.3 Ma ago, as indicated by molluscs belonging to the Prosodacnomya dainellii and P. vutskitsi littoral biozones. As no clinoforms are present on seismic profiles, the northern foreland must have been a shallow underwater high at that time.

The Northern Imbricate Zone in the mountains were dryland during most of the Late Miocene. Sedimentation started here approximately coevally with the arrival of the delta system at the foot of the mountains. Flooding ensued on a dissected topography. The delta sediments with dominantly sublittoral fauna above the thin littoral base sands indicate rapid transgression.

Late Miocene sedimentation was accompanied by small-scale movements of strike-slip character. More important tectonic deformations followed afterwards: strike-slip to north-vergent reverse displacements happened along the northern master fault of the Mecsek and roughly parallel planes.

Keywords: Mecsek Mts, Northern Imbricate Zone, Upper Miocene, Pannonian, Lake Pannon, neotectonics

Összefoglalás

A Kelet-Mecsek északi peremén fekvő Északi-pikkely bonyolult felépítésú, részben neogén üledékekkel fedett keskeny, kiemelt alaphegységi sáv. Erôsen tektonizált terület fiatal, miocén utáni szerkezeti mozgásokkal. A területen a pannóniai üledékek legnagyobb kiterjedésben Nagymányok körül találhatók meg. 2015-ben keletkezett ideiglenes feltárásokat dokumentáltunk üledék- és szerkezetföldtani szempontból, réteg szerinti ôsmaradványgyújtés kíséretében. A mintegy 120 m vastag Pannon-tavi rétegsort viszonylag finomszemú, puhatestú-maradványokban gazdag agyagkőzetliszt-finomhomok összlet alkotja a vékony $(<3 \mathrm{~m})$, kavicsos durvahomok anyagú idősebb pannóniai rétegek fölött. A faunában uralkodó kagylók mellett csiga-, kagylósrák-, hal- és növénymaradványok is elókerültek. A legidősebb rétegek a Prosodacnomya dainellii - P. vutskitsi puhatestű zónákba, míg a finomabb szemú fedőüledékek a Congeria rhomboidea zónába tartoznak. 
A pannóniai üledékképződés kezdetben csak az északi elótérben indult meg, nyílttavi, agyagmárgás-aleuritos rétegsor formájában (Száki Agyagmárga). Ôslénytani vizsgálatok hiányában az elöntés kezdetének időpontját a Mecsek előtt húzódó keskeny árokban nem ismerjük; a tőle északra húzódó széles hát elöntése puhatestú adatok alapján 8,9 M év után történt. Ezt az északról érkező, alp-kárpáti eredetû deltarendszer finomhomok-agyag hordalékának felhalmozódása váltotta fel (Újfalui Formáció), a Prosodacnomya dainellii és P. vutskitsi litorális molluszkazónába tartozó puhatestúek szerint 7,3 millió évvel ezelőtt. A szeizmikus geometria alapján az északi előtér ekkor sekély vízzel borított hátság lehetett, míg az Északi-pikkely szárazulat volt. Itt az üledékképződés a deltarendszernek a Mecsek északi pereméhez történő érkezésével megközelítőleg egyidőben kezdődött meg. Az elöntés tagolt domborzatú térszínt ért. A helyi, mecseki forrásból származó, partközelben lerakódott vékony kavicsos homokrétegek után következő, jórészt szublitorális faunájú deltaüledékek következtek. A pannóniai üledékképződés során kisebb léptékú eltolódásos mozgások zajlottak. Erősebb tektonikai hatások annak lezárulása után érték a területet: a hegység északi peremvetője és vele közel párhuzamos sík(ok) mentén eltolódásos-feltolódásos szerkezeti mozgások történtek.

Kulcsszavak: felsố-miocén, neotektonika, Pannon-tó

\section{Bevezetés}

A Kelet-Mecsek északi peremén fekvő Északi-pikkely szerkezetileg az egyik legbonyolultabb terület a hegységben (WEIN 1965). Az Északi-pikkely a Kelet-Mecsek központi részével megegyező kőzetekből álló, ám attól neogén üledékekkel elválasztott és részben fedett, keskeny, kiemelt alaphegységi sáv (1. ábra). Igen tektonizált terület, nagyszámú szerkezeti elemmel és fiatal (posztmiocén) szerkezeti mozgásokkal (TARI 1992, CsONTOS et al. 2002). Területén a Pannon-tavi üledékek legnagyobb kiterjedésben Nagymányok körül találhatók meg. Míg a Nyugat-Mecsekben vagy a Mórágyi-rög környékén a közelmúltban részletesen vizsgálták a pannóniai képződményeket ôslénytani, rétegtani és tektonikai szempontból is a Pannon-tóra vonatkozó, a közelmúltban kialakult fejlődéstörténeti kép (MAGYAR 2010) felhasználásával (pl. CZICZER 2014; SEBE et al. 2013, 2015; SzTANó et al. 2015), addig az Északi-pikkely felsô-miocén üledékeivel utoljára KLEB (1973) foglalkozott részletesen. Jelen munka apropóját az adja, hogy 2015-ben egy mészkő- bánya nyitásához kapcsolódó földmunkáknak köszönhetôen több ideiglenes feltárás keletkezett Nagymányoktól délre. A felszínre bukkant pannóniai rétegsor mecseki viszonylatban nagy vastagságúnak számít, ôsmaradványokban gazdag, és eltér a hegységperemen megszokott durvahomokos összletektől. A munka célja a friss és a közelükben található régebbi feltárások dokumentálása és értelmezése volt a tágabb földtani környezet keretében, képet adva ezzel a terület pannóniai fejlődéstörténetéról.

\section{Vizsgált terület}

Nagymányok környékén a földtani megkutatottság fóleg a szénbányászatnak köszönhető (WEIN 1965). A falutól délre közel 100 évig múködött mélymúvelésú szénbánya, jelenleg egy mészkőbánya üzemel. Az alaphegységet mezozoos kőzetek alkotják: triász karbonátok, alsó-jura szenes összlet és a fedô mészmárgás rétegsor (VADÁsz 1935, HÁMOR 1966, HÁmOR et al. 1968) (1. ábra). Ezek kis területen vannak

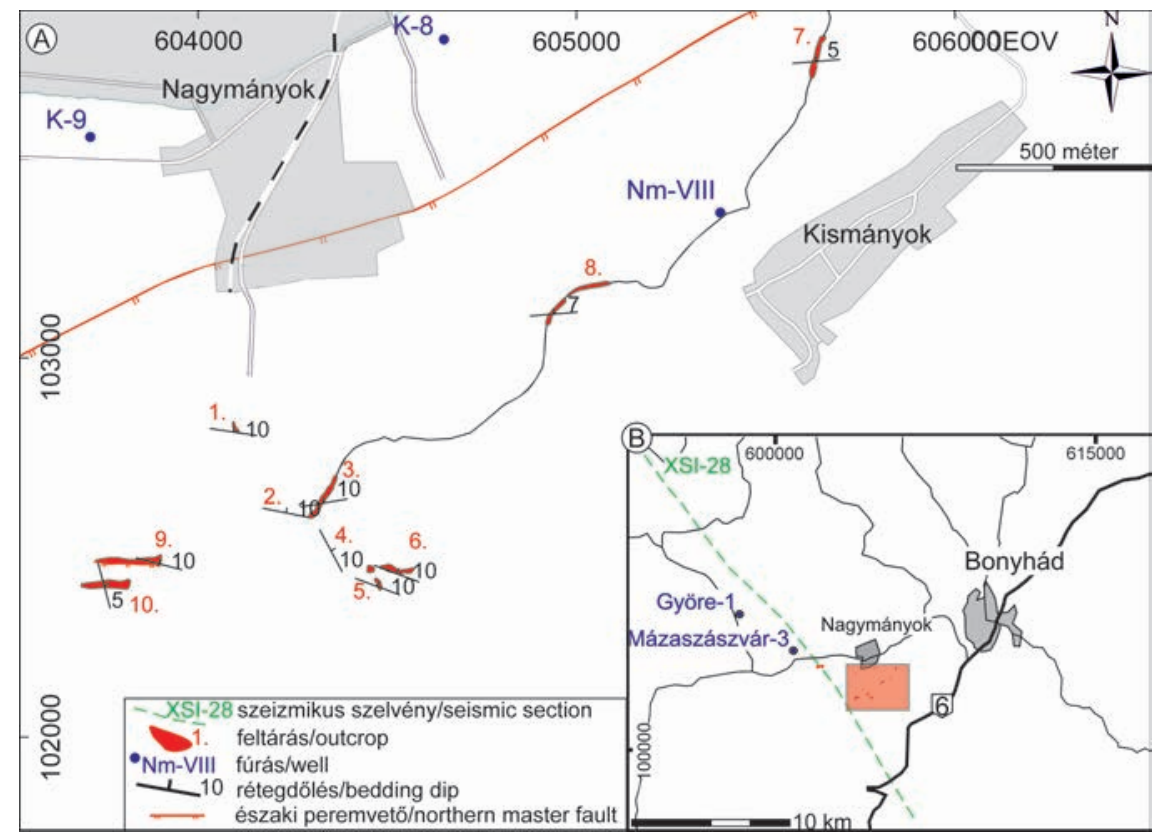

1. ábra. A) A vizsgált feltárások és fúrások a térképen. B) Áttekintő ábra a terület és a bemutatott szeizmikus szelvény (6. ábra) helyzetéről

Figure 1. A) The investigated outcrops and boreholes on the map. B) The overview map shows the location of the study area and the seismic section 
felszínen, a terület nagy részét a rájuk települő pannóniai (felső-miocén) üledékek borítják, a legtöbb helyen kvarter — rendszerint lösz és lejtôtörmelék — fedővel. A szúk vizsgálati területen a pannóniainál idősebb miocént csak egy vékony, erôsen bontott, tektonikusan becsípett riolittufa képviseli, melyet HÁMOR (1970) az „alsó riolittufához” sorolt, azaz alsó-miocénnek tekintett. Kevesebb mint 1 kmre, a Völgység-patak vízválasztójának déli oldalán, Hidas felé azonban már nagy kiterjedésben találhatók meg az alsóés középső-miocén üledékek.

A vizsgált területen az alaphegység eróziós felszínére legfeljebb néhány méter vastag limonitos, éretlen, kavicsos durvahomok, majd ,kék agyag” települ, amely faunája alapján pannóniai korú. Ezen rétegek molluszkáival részletesen LÓRENTHEY Imre (1890, 1893) foglalkozott; 1890-es munkájában a környék általános földtani felépítését is ismertette.

\section{Módszerek}

Jelen munka során lehetôség nyílt LőRENTHEY rétegsorának pontos üledékföldtani leírására és fölfelé történő kiegészítésére. A vizsgált $2 \mathrm{~km}^{2}$-es területen 10 feltárást útbevágásokat, bányát és természetes kibúvásokat — írtunk le (I. táblázat). Ezek többsége friss, de LóRENTHEY (1890, 1893) feltárásai is köztük voltak.

I. táblázat. A feltárások elhelyezkedése

Table I. Location of the outcrops

\begin{tabular}{|c|l|c|}
\hline $\begin{array}{c}\text { Feltárás } \\
\text { száma }\end{array}$ & \multicolumn{1}{|c|}{ Leirás } & EOV \\
\hline 1 & Rezsö-táró bejárata fölött, $4 \times 2 \mathrm{~m}$ (Lörenthey) & $604182 ; 102843$ \\
\hline 2 & út melletti vizelvezetö csatorna, $3 \times 1 \mathrm{~m}$ & $604320 ; 102630$ \\
\hline 3 & Kismányokba vezetö bányaút, nagy bevágás, 100×20 m & $604409 ; 102654$ \\
\hline 4 & $9 \times 4 \mathrm{~m}$ természetes fal & $604448 ; 102526$ \\
\hline 5 & régi földút bevágásában, $3 \times 1 \mathrm{~m}$ (Lörenthey) & $604560 ; 102436$ \\
\hline 6 & 5 -töl K-re a szurdokvölgyben, $10 \times 7 \mathrm{~m}$ & $604601 ; 102470$ \\
\hline 7 & az bányába vezetô út Kismányok felöli oldala, $60 \times 4 \mathrm{~m}$ & $605707 ; 103798$ \\
\hline 8 & az útbevágás legmagasabban fekvõ része, $45 \times 3,5 \mathrm{~m}$ & $604939 ; 103112$ \\
\hline 9 & mészköbánya, alsó szint & $603901 ; 102461$ \\
\hline 10 & mészköbánya, felső szint & $603712 ; 102379$ \\
\hline
\end{tabular}

A munka legfontosabb része az ideiglenes feltárások leírása volt. Az üledékes bélyegek megfigyelése és az ősmaradványok gyújtése rétegekre lebontva történt. A feltárások részletes dokumentációja KovÁcs (2017) munkájában olvasható. A fosszíliák preparálását a PTE TTK Földtani és Meteorológiai Tanszékén végeztük, a konzerválás polivinil-butirállal történt. A gyűjtött ősmaradványok az MTM Növénytárában és Őslénytani és Földtani Tárában lettek elhelyezve, leltári számuk HNHM-PBO 2016.4.2., HNHM-PBO 2018.366.2., INV 2018.161-2018. 205. és VER 2018.1890-1893. Az egyik kagyló az MTM Bakonyi Természettudományi Múzeumának gyújteményéből származik, leltári száma 2016.8.3. A mikropaleontológiai mintákat $\mathrm{H}_{2} \mathrm{O}_{2}$-vel kezeltuik. Az eredmények tágabb környezetbe illesztéséhez tanulmányoztuk a környékbeli szeizmikus reflexiós szelvényeket és a közelükbe esô fúrási rétegsorokat.

\section{A pannóniai rétegsor}

A vizsgált feltárásokat korrelálva az alaphegység fölött egy $25 \mathrm{~m}$ vastag folyamatos rétegsort lehetett összeilleszteni (2. ábra). A 8. feltárás rétegtanilag jóval a többi fölött

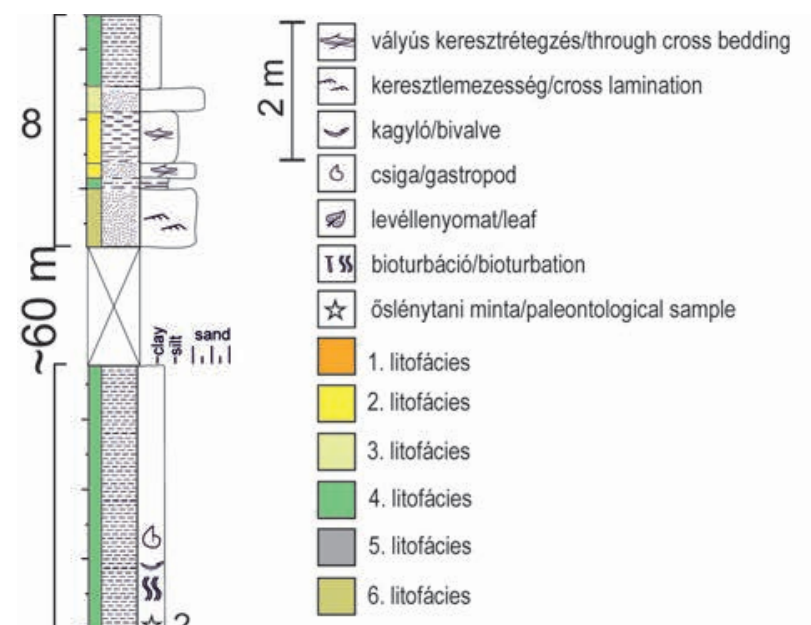

3

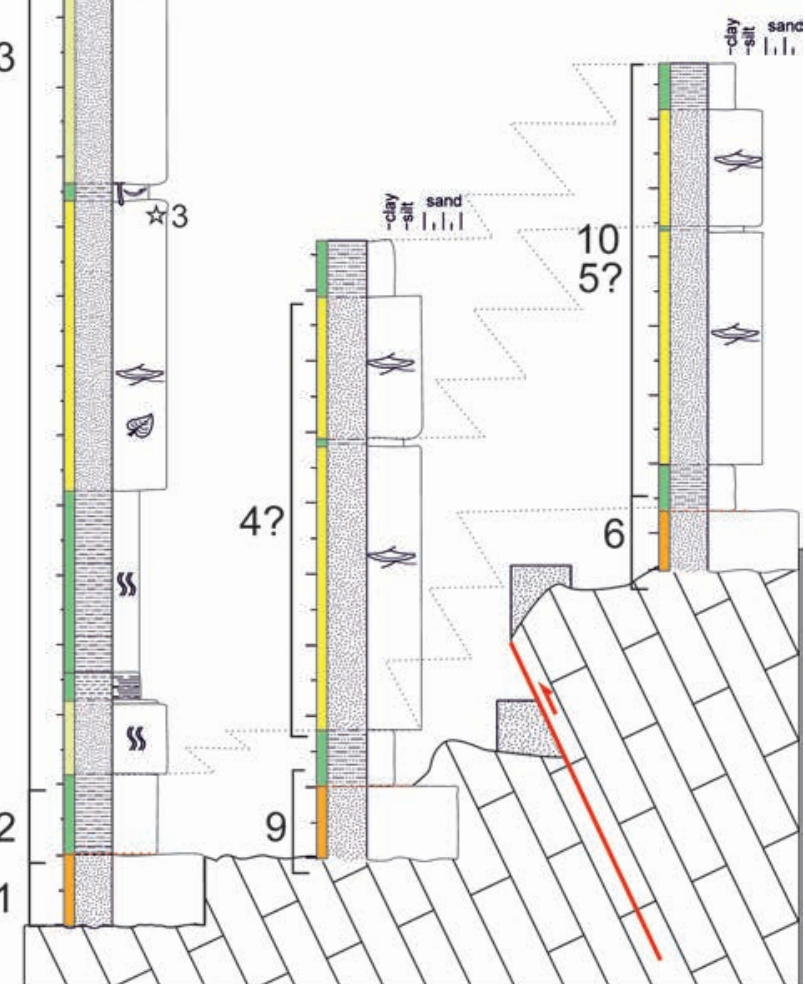

2. ábra. A terület pannóniai rétegsorai és azok korrelációja az alaphegység felett. Utóbbi magassági ábrázolása a pannóniai képződményekhez képest nem méretarányos

Figure 2. Sedimentary logs of the study area with the positions of the individual outcrops. Basement topography is not to scale with Pannonian sediment thicknesses 
helyezkedik el, köztük az Nm-VIII fúrás és a dőlésadatok alapján 60 m üledék nem vizsgálható. A kapcsolatot a két szakasz között a Nm-VIII jelenti, ami 118 m pannóniai üledéket tárt fel.

A folyamatosan leírható pannóniai rétegsor három egységből áll. A középső-triász mészkőre szögdiszkordanciával max. $3 \mathrm{~m}$ kavicsos durvahomok települ, amire finomszemú homokrétegek következnek 15-17 m vastagságban. A rétegsor egy kb. $6 \mathrm{~m}$ vastagságú pelit összlettel zárul.

\section{Jellemzó litofáciesek és értelmezésük}

A rétegsorban hat jellemző kôzettípust lehetett elkülöníteni (3. ábra). Ezeket lentról felfelé haladva ismertetjük. Rétegsorbeli elhelyezkedésüket a 2. ábra mutatja.

\section{Kavicsos durvahomok}

Szerkezetmentes, rosszul osztályozott üledék, a pannóniai üledékek bázisát képezi (3. ábra, A). Közvetlen a

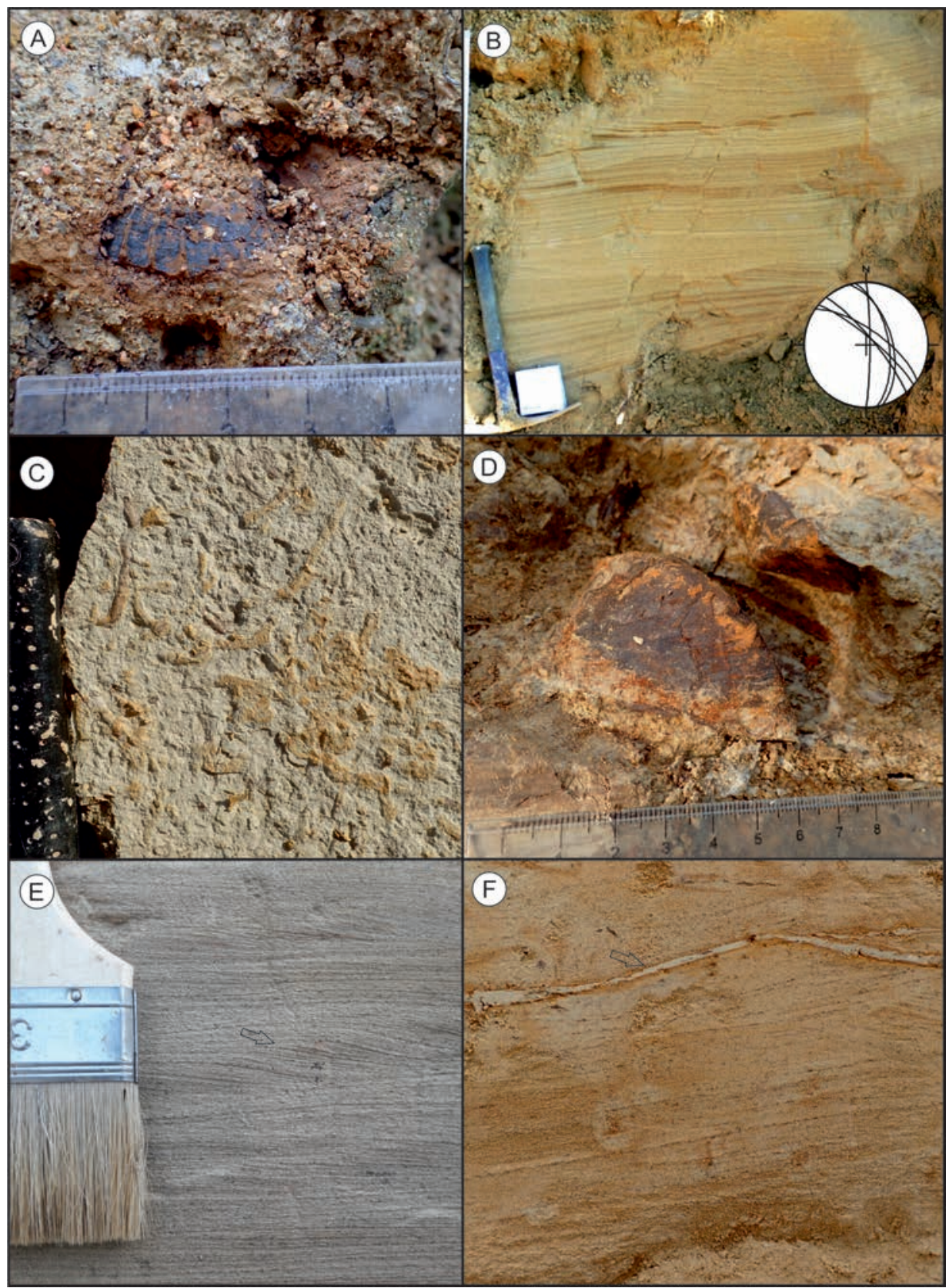

3. ábra. Jellemző litofáciesek a feltárások számaival

A) Kavicsos durvahomok Lymnocardium schmidti egy teknőjének köbelével (6.), B) vályúsan keresztrétegzett finomhomok szinszediment vetőkkel és azok sztereogramjával (3.), C) agyaggal kitöltött, $1 \mathrm{~cm}$ átméröjủ horizontális járatok a kőzetlisztes agyagréteg talpán (3.), D) finomszemủ homokréteg összehalmozott Congeria rhomboideák kőbeleivel (3.), E) kúszó keresztlemezes finomszemű homok (8.), F) keresztlemezes finomhomok agyaglepellel kiemelve (8.)

Figure 3. Typical sedimentary structures in the investigated outcrops

A) pebbly sand, with a Lymnocardium schmidti mould B) trough cross-bedding in sand with synsedimentary faults, C) 1 cm diameter horizontal burrows in the bottom of silt/clay layers, D) very fine grained sand with Congeria rhomboidea moulds, E) climbing cross-laminated sand, F) crosslaminated sand with a clay drape 
középső-triász mészkőre (Lapisi és Zuhányai Mészkő Formáció) települ. A mészkőbánya felső szintjének (10. feltárás) nagy, letisztított kőzetfelszínén megfigyelhető, hogy a mészkő karrosodott, és a karsztos mélyedésekbe azonnal a pannóniai homok települ. A homok anyaga földpát, kvarc és gránittörmelék, a szemcsék alig koptatottak. Kötőanyaga karbonát, illetve limonit. Maximális vastagsága $3 \mathrm{~m}$. Sok kagylóteknő-lenyomat és -kőbél található benne.

A földpátgazdag, alig koptatott, éretlen kőzetanyag arra utal, hogy keveset szállítódott, közvetlen közelről lepusztuló anyagról van szó. A gránittörmelék alapján a forráskőzet az innen néhány száz méterre délre ma is megtalálható alsó-miocén Szászvári Formáció. A szemcseméret és a molluszkák megtartása alapján erősen mozgatott vízben rakódott le.

\section{Gipszhomokréteg a Pannon-tóban}

A durvahomokban található kavicsok közt a mészkőbánya (9., 10. feltárás) északi részén, a tektonikai adatok c. fejezetben tárgyalt nagy feltolódás északi előterében egy különleges kőzettípus is előfordult (4. ábra). A jellemzően $<5$ cm nagyságú, jól koptatott, fekete kavicsok porózusak,

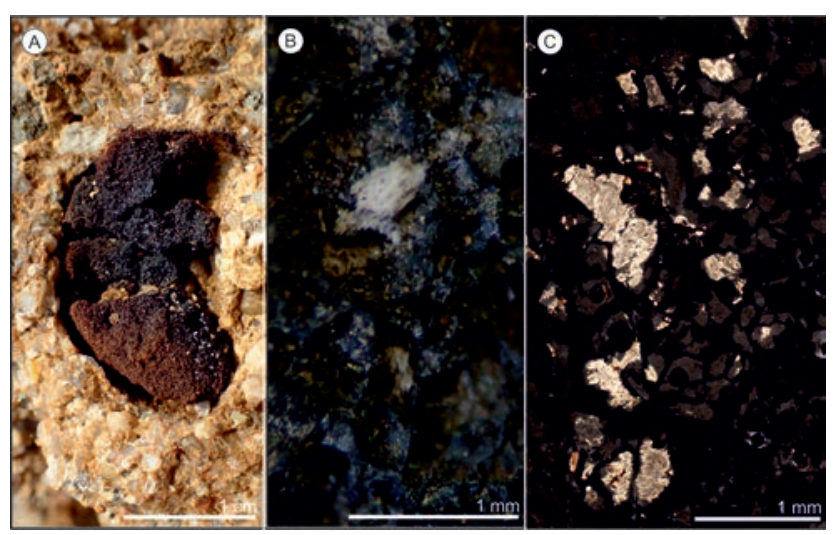

4. ábra. Fekete, porózus, Mn-oxid anyagú, eredetileg gipszhomokot is tartalmazó kavics a durvahomokban. A) a kavicsos homok makroszkópos képe; B) kavics közelképe; egyes üregekben még látható a gipsz anyagú homokszemcse maradványa; $\mathrm{C}$ ) vékonycsiszolat (keresztezett nikolok közt)

Figure 4. Black, porous pebble (made of $\mathrm{MnO}$ ) in the very coarse sand, which originally also contained gypsum sand. A) macroscopic view of the pebbly sand; B) close up photo of the pebble; the gypsum sand residue is still visible in some of the cavities; $C$ ) cross section $(\times N)$.

puhák, kézzel morzsolhatók és nagyon könnyúek, úsznak a vízen. Szerkezetük nem mutat irányítottságot, pórusaik izometrikusak, 0,1-1 mm átmérőjúek. A fekete anyag $\mathrm{H}_{2} \mathrm{O}_{2}$-ra füstölve pezseg, azaz Mn-oxid-vegyület. Sztereomikroszkóp alatt a pórusok egy részében láthatóvá válik egy kristályos szemcse vagy annak maradéka. Vékonycsiszolatban a kristályok gipsznek bizonyultak optikai tulajdonságaik alapján: szálas-rostos megjelenés, hasadási nyomvonalak, kicsi kettőstörés, elsőrendû szürke interferenciaszín. A mészkőbányában dolgozó gépkezelő elmondása szerint ugyanez az anyag valamivel mélyebben a durvahomokban egy 10-15 cm vastag, folyamatos réteg formájában is előfordult; ottjártunkkor sajnos ezt már letermelték. A ma porózus anyag tehát eredetileg egy gipsz- homokréteg lehetett, amit Mn- és Fe-oxid cementált homokkővé. Később a homokszemcsék nagy része kioldódott, a homokkőnek a cementje maradt meg, maga a gipszhomok csak nyomokban.

\section{Vályúsan keresztrétegzett finomszemú homok}

Világos sárgásbarna, jól osztályozott, finomszemú homok (3. ábra, B). A szemcseanyag az összes homokban kvarc és muszkovit, a kötőanyag karbonát. A vályúk kötegvastagsága $10-25 \mathrm{~cm}$. A rétegsor legmagasabb szakaszán néhány $\mathrm{m}$ széles és kb. fél m mély csatornakitöltéseként is megjelenik ugyancsak keresztrétegzett homokba vágódva, ahol a csatorna alját 2-8 cm hosszú szürke agyagkavicsokból álló réteg béleli. Molluszkák elszórtan találhatók benne. A szemcseanyag alapján érett, messzirôl szállítódott üledék, ami a csendes áramlási tartományban rakódott le, az áramló közeg vastagsága minimum $1,75 \mathrm{~m}$ lehetett.

\section{Bioturbált, molluszkatörmelékes finomszemú homok}

A legelterjedtebb litofácies, világos sárgásbarna, jól osztályozott finomhomok. A rétegsor alsó részén elszórtan apró (<8 mm) kvarc- és tûzkőkavicsok vannak benne. Néhány helyen gyengén látszik az elsődleges szerkezet (vályús keresztrétegzés) maradványa, de ezt a bioturbáció eltünteti. Sok molluszka héjtöredéket és lenyomatot tartalmaz, emellett halmaradványok és két növénylenyomat is előkerült. Az életnyomok tengeri beosztása BABINSZKI et al. (2003) alapján a Pannon-tóra is alkalmazható, így az 1-2 cm átmérôjú vertikális járatok a Skolithos ichnofáciesbe tartoznak. Ez szintén érett, messziről szállítódott üledék, de az alsóbb részeken a közeli térszínek lepusztuló anyaga is keveredett hozzá.

\section{Szerkezet nélküli kőzetlisztes agyag}

Világos kékesszürke, kagylós elválású kőzet. Rétegtalpán kb. $1 \mathrm{~cm}$ átmérôjú, kacskaringós horizontális járatok vannak (3. ábra, C). Az üledékben sok ép csiga és duplateknős kagyló található. Az ősmaradványok szórtan, jellemző irányítottság nélkül ôrződtek meg. Ez az üledék nyugodt, vízmozgásmentes időszakot jelez, amit a puhatestúek megtartása és fajösszetétele (1. alább) is alátámaszt. Az életnyomok a Cruziana ichnofáciesbe sorolhatóak.

\section{Összehalmozott molluszkákat tartalmazó, finomszemú homok}

Ez a kőzettípus egyetlen rétegben figyelhető meg a 3. feltárás felső szakaszán, a kőzetlisztes agyagrétegek között (3. ábra, D). Rengeteg nagy méretû kagylókóbél fordul elő a rétegben összehalmozva, jellemzően domború oldalukkal felfelé. Elsődleges üledékszerkezet a bioturbáció miatt nem látszik, azonban az összemosott héjak alapján egy pillanatszerú behordási eseményre, például egy vihar üledékére következtethetünk. 
Kúszó keresztlemezes, finomszemú homok

Ez a jól osztályozott finomhomok (3. ábra, E) csak a rétegsor legmagasabb szakaszán fordult elő (8. feltárás). Ôsmaradvány nem került elő belőle. A keresztlemezesség asszimetrikus, azaz a szerkezet áramlási fodrokhoz tartozik.A kúszás pedig folyamatosan utánpótlódó homokot szállító áramlásra utal. Ezeket néhol agyaglepel fedi (3. ábra, F), ami az áramlás megszúnését jelzi.

\section{Ösmaradványok}

A vizsgált feltárásokból több mint 150 makrofosszíliát gyưjtöttünk Ezek túlnyomórészt puhatestûek, de előkerült halcsigolya, -pikkely, úszósugártüske és otolith, valamint néhány levéllenyomat is (I. tábla). Az egyes taxonok litofácies szerinti eloszlását a II. táblázat mutatja be.

A kavicsos durvahomokban kevés, nagy méretú faj van nagy egyedszámmal képviselve. Az üledékből összehalmozott kőbelek, lenyomatok és héjtöredékek kerültek elő. A $L$. schmidti és a C. rhomboidea mind a litorális, mind a szublitorális övben megtalálható, míg a Dreissena auricularis egyértelmúen litorális forma (JUHÁSZ \& MAGYAR 1993; MAGYAR 1995). LőRENTHEY (1893) HofMANN gyújtéséből olyan tipikus litorális fajokat is határozott innen, mint a Lymnocardium arpadense (a leírása alapján valószínúleg $L$. diprosopum) és a Congeria balatonica.

A finomszemú homokban változatosabbá válik a fauna, a litorális Dreissenomya intermedia mellett megjelenik a szublitorális környezetre jellemző Lymnocardium szaboi, L. stevanovici és Paradacna okrugici. A rétegekben a puhatestűek elszórtan fordulnak elő, jellemzően kisebb méretűek és vékony héjjal rendelkeznek. Megtartásuk változatos, héjtöredékek és kőbelek mellett kétteknős példányok is előkerültek. A táblázatban felsorolt fajok a korábban felderített ökológiai igények (MAGYAR 2010) alapján kisebb energiájú, nyugodtabb környezethez alkalmazkodtak. Ôsmaradványok főképp a bioturbált homokokból kerültek elő.

Az aleurit-agyag rétegeiból szintén elszórtan kerültek elő az ősmaradványok. Itt a Prosodacnomya sp. és a Dreissena auricularis kivételével a szublitorális zónára (vagy a litorális és szublitorális zónákra együttesen) jellemző fajok találhatók. A kagylók túlnyomó többsége két teknővel őrződött meg. Az általunk is megtalált fajokon túl LőRENTHEY (1890, 1893) számos tipikusan szublitorális fajt sorol fel az agyagból: Congeria croatica, C. zagrabiensis, Lymnocardium cristagalli, L. majeri, „Pontalmyra” otiophora, Valenciennius reussi.

LŐRENTHEY (1893) az összes üledéktípusból összevonva 38 puhatestú taxont sorolt fel Nagymányokról. Az általunk azonosított formák közül csak a Pisidium sp. nem szerepel a listáján (a mi Paradacna sp.-ként jelölt formánk azonos lehet LÓRENTHEY „Limnocardium nov. form.” taxonjával). Érdekes, hogy a korhatározás szempontjából fontos Prosodacnomya nemzetségből ő is csak egyetlen töredéket talált (nála „Limnocardium semisulcatum”).

A puhatestú maradványok alapján biosztratigráfiailag a kavicsos durvahomok (amennyiben LőRENTHEY diagnózisa helyes, és valóban L. diprosopumot tartalmaz) legvalószínúbben a Prosodacnomya dainellii litorális puhatestû́ zónába tartozik, míg a fedőjében feltárt finomabb szemú üledéksor a Congeria rhomboidea szublitorális biozónába sorolható (sensu MAGYAR \& GEARY 2012). Az utóbbiban talált egyetlen Prosodacnomya teknő áthalmozással kerülhetett a litorális övből a szublitorálisba. Megtartása nem

II. táblázat. Az előkerült ősmaradványok gyakoriság szerint rendezve Table II. Fossils of the study area

\begin{tabular}{|c|c|c|c|c|c|}
\hline Faj & $\begin{array}{c}\text { Kavicsos } \\
\text { durvahomok }\end{array}$ & $\begin{array}{c}\text { Keresztrétegzett /bioturbált } \\
\text { finomhomok } \\
\end{array}$ & $\begin{array}{c}\text { Szerkezetmentes } \\
\text { közetlisztes agyag }\end{array}$ & $\begin{array}{c}\text { Összehalmozott molluszkás } \\
\text { finomhomok }\end{array}$ & $\begin{array}{c}\text { Kúszó keresztlemezes } \\
\text { finomhomok }\end{array}$ \\
\hline Lymnocardium schmidti & $\mathrm{x}$ & $\mathrm{x}$ & & $x$ & \\
\hline Lymnocardium szaboi & & $\mathrm{x}$ & $x$ & & \\
\hline Lymnocardium stevanovici & & $\mathrm{x}$ & $x$ & & \\
\hline Lymmocardium ferrugineum & $\mathrm{x}$ & & & & \\
\hline Lymnocardium banaticum & $\mathrm{x}$ & & & & \\
\hline Caladacna steindachneri & & $\mathrm{x}$ & $x$ & & $\mathrm{x}$ \\
\hline Prosodacnomya sp. & & & $\mathrm{x}$ & & \\
\hline Paradacna okrugici & & $\mathrm{x}$ & & & \\
\hline Dreissenomya intermedia & & $\mathrm{x}$ & & & \\
\hline Dreissena auricularis & $\mathrm{x}$ & & $x$ & & \\
\hline Congeria rhomboidea & $x$ & & $x$ & $x$ & \\
\hline Pisidium sp. & & & $x$ & & \\
\hline Zagrabica sp. & & & $x$ & & \\
\hline halcsontok és -pikkelyek & & $\mathrm{x}$ & & & \\
\hline Umbrina cirrhosoides otolith & & & $x$ & & \\
\hline Celtis sp. levél & & $\mathrm{x}$ & & & \\
\hline Alnus cecropiifolia levél & & $\mathrm{x}$ & & & \\
\hline
\end{tabular}


tette lehetővé a pontos határozást, de a példány vagy a. dainellii, vagy a. vutskitsi fajhoz tartozik. A rétegsor bázisán lévő durvahomok vékony, és üledékfolytonossággal települ rá a finomhomok-agyag rétegsor, ezért nem indokolt feltételezni, hogy a két képződmény kora lényegileg különbözne. A vizsgált rétegsor kora így legvalószínúbben 7,5 és 7,0 M év közé tehetô, de ennél fiatalabb miocén kor sem zárható ki teljesen.

LŐRENTHEY (1890) említ kisemlősfogakat Nagymányokról, amelyek esetleg segíthetnének a kor pontosításában. Sajnos ezek a maradványok ma nem találhatók meg sem a Magyar Természettudományi Múzeum Őslénytárában, sem a Magyar Bányászati és Földtani Szolgálat földtani gyújteményében.

A makrofosszíliák gyưjtésén kívül mikropaleontológiai vizsgálatokat is végeztünk. A minták helyét a 2. ábrán jelöltük. Az előforduló mikrofosszíliákat gyakorisági sorrendben a 3. táblázat tartalmazza. amely egy vastagfalú, díszített forma és feltehetően a litorális zónából került nagyobb vízmélységbe (SzUROMINÉ KoreCZ 1991).

A Candonákon kívül csak két egyéb genust (Cypria tocorjescui HANGANU, Loxoconcha alitera KRSTić) találtunk, azokat is nagyon alacsony példányszámban. Korábbi vizsgálataink szerint (SzUROMINÉ KORECZ 1991) a Cypria tocorjescui HANGANU és a Candona (Hastacandona) subgenusba tartozó fajok a sekélyebb vizek (< 15 m) lakói lehettek.

Az együttesben számos juvenilis egyedet figyeltünk meg, ami az asszociáció autochton jellegét bizonyítja (RUIZ et al. 2003). Nagyon kevés a kettős teknőjú példány, ami nem túl gyors üledékképződésre utal (HoLMES 2001).

A tipikus parti, litorális genusok (Cyprideis, Hemicytheria, Amnicythere, Loxoconcha) szinte teljes hiánya mélyebbvízi, szublitorális vízmélységre utal (BoOMER et al. 2005).

III. táblázat. A 3. feltárásból leírt mikrofauna

Table III. Microfauna of the outcrop no. 3

\begin{tabular}{|c|c|c|}
\hline 1. minta & 2. minta & 3. minta \\
\hline Candona (Caspiolla) parabalcanica KRSTIĆ & Candona (Caspiolla) parabalcanica KRSTIĆ & Candona (Caspiolla) parabalcanica KRSTIĆ \\
\hline Candona (Caspiolla) sp. & Candona (Caspiolla) sp. & Candona (Caspiolla) sp. \\
\hline Szivacstü & Candona (Reticulocandona) orientalis KRSTIĆ & Candona (Hastacandona) longitesta KRSTIĆ \\
\hline \multirow[t]{7}{*}{ Radiolaria (átkristályosodott, koptatott) } & Candona (Hastacandona) pontica AGALAROVA & Candona (Hastacandona) pontica AGALAROVA \\
\hline & Candona (Hastacandona) longitesta KRSTIĆ & Candona (Hastacandona) sp \\
\hline & Cypria tocorjescui HanganU & Candona (Zalanyiella) sp. \\
\hline & Candona (Sirmiella) arcuatoides KRSTIĆ & Candona (Reticulocandona) sp. (juv) \\
\hline & Candona (Zalanyiella) sp. & Cypria tocorjescui Hanganu \\
\hline & Candona (Typhlocypris?) sp. & Leptocythere (Amnicythere) sp. \\
\hline & Loxoconcha alitera KRSTIĆ & \\
\hline
\end{tabular}

A szerkezetmentes, kőzetlisztes agyagrétegből vett $\mathbf{1}$. mintából rendkívül szegényes és rossz megtartású ostracoda fauna került elô. A Candona (Caspiolla) parabalcanica KR. és a Candona (Caspiolla) sp. néhány sérült félteknôje alkotta az együttest. Ez a közel monospecifikus összetétel, továbbá a kisebb juvenilis példányok hiánya arra enged következtetni, hogy a szegényes együttes allochton.

Az ostracodák mellett még kevés szivacstútöredék, átkristályosodott radiolaria példány is előfordult. Ennek alapján az üledékképződés során a felszínen lévő idősebb képződmények anyaga is belekerült a vizsgált rétegsorunk kőzetanyagába.

Szárazföld közelségét jelzi, hogy a kőzetanyag hidrogén-peroxidos kezelése után több, különböző forrásanyagú kavics (2-5 mm) is előkerült az iszapolási maradékból.

A szintén szerkezetmentes, kôzetlisztes agyagból, de felsóbb szakaszról vett 2. minta jó megtartású és diverz ostracoda együttest tartalmazott. Az együttesben domináltak a Candona genus tagjai (az együttes 99\%-a), melyek egy kivételével sima, vékony, megnyúlt teknőjű formák, melyek nagyobb mélységek lakói (HoFMAN 1966). Az egyetlen kivétel a Candona (Reticulocandona) orientalis KRSTIĆ faj,
A 3. minta finomszemú homokjában viszonylag jó megtartású (finomhomokkal kitöltött félteknôk) és diverz ostracoda faunát válogattunk ki. Az asszociáció nagy hasonlóságot mutatott a korábban ismertetett 2. minta (aleurit, agyag) együtteséhez: mindkettőben a Candonák (elsősorban a Caspiolla- és Hastacandona-félék) domináltak, a Candonákon kívül csak néhány Cypria tocorjescui Hanganu és Leptocythere (Amnicythere) sp. példányt találtunk. A juvenilis egyedek jelenléte itt is igazolta az együttes autochton jellegét (RuIz et al. 2003). Az ostracoda teknőknek csak kisebb hányada volt kettős teknő, ami nem túl gyors sebességú üledékképződésre utal (HoLMES 2001).

Az ostracoda együttes leggyakoribb fajának (Candona (Caspiolla) parabalcanica KRSTIĆ) sótartalomigényét mio-mezohalinnak (3-9 ezrelék) tartjuk (SzUROMINÉ KoRECZ 1991), ezért feltételezzük, hogy az egykori üledékgyújtő vize is az említett két érték között ingadozhatott. Édesvízi-oligohalin (0-3 ezrelék) sótartalomigényú taxont (például: Ilyocypris, Candona [Candona] stb.) nem találtunk.

Az ostracoda együttes tagjainak nagyobb részét KRSTIC (1968, 1972a, b) írta le a Pannon-medence szerbiai részének „felsô-pontusi” képződményeiből. 


\section{A rétegsor értelmezése}

A rétegsor a kőzetkifejlődések és ősmaradvány-tartalom együttes figyelembe vételével értelmezhető.

A rétegsorban sekélyvízi, és hullámbázis alatti, nyugodt környezet üledéktípusai fordulnak elő. Az alsó, folyamatosan vizsgálható részen fokozatos szemcseméret-csökkenés figyelhető meg. A durvahomok litorális üledék, a közelrôl származó törmelékanyag gyenge átmozgatásával keletkezett, a terület víz alá kerülését jelzi.

A gipszhomok megjelenése a rétegsor alján sekély, bepárlódó, valamilyen szinten sós vízre utal. Míg a badeni és szarmata emeletekben nem ritka az evaporitok előfordulása, köztük gipszé, illetve anhidrité sem (pl. SELMECzI et al. 2012), a Pannon-tóban nem sok helyről ismerjük jelenlétét. Rudabánya idős pannóniai mocsári agyagjaiban rózsákban vagy változó vastagságú kötegekben figyeltük meg. A Bakony DK-i előterében JÁMBOR $(1980,75$. o.) ír le gipszkiválásokat az Ôsi Tarkaagyag repedéseiben, képződésüket az — egyébként is sekély — üledékgyưjtő kiszáradásához köti. Térben és időben a legközelebbi gipszelőfordulást BARABÁS András (2010) írta le a Somberek-2 fúrásból a szarmata és pannóniai képződmények határáról. A 1,5cm vastag gipszréteget az eredeti fúrásleírás a szarmata összlethez sorolja; az előzőekkel ellentétben mélyvízi üledékek között található. A nagymányoki előfordulás új helyszínt ad hozzá az eddig ismertekhez, és a vízszint többszöri mozgásáról tanúskodik. Hogy a gipszhomok eredetileg homok méretû szemcsékként vált-e ki, vagy egy korábbi, akár agyaggal vegyes réteg eróziójával keletkezett, az nem eldönthető. A szemcsék nem vagy alig koptatott volta mindenesetre igen rövid idejû mozgatásra utal. A gipszhomokrétegeket leülepedésük után Mn- és Fe-oxid-ásványok cementálták. Egyes rétegek, amelyek gyorsan betemetődtek, megmaradtak; másokat a Pannon-tó hullámverése felszaggatott, ezek koptatott kavicsok formájában ôrződtek meg a partközeli üledékben. Az, hogy ennyire puha kőzetanyag a hullámveréses övben megmaradhatott, gyors betemetődésre utal, a vízszint, illetve a partvonal nem sokáig lehetett stabil.

Az ezt követô finomhomok, majd kőzetlisztes agyagrétegek faunájukkal egyuitt az erózióbázis szintjének látszólagos emelkedését és az egyensúlyi partprofil eltolódását jelzik. A vályús keresztrétegzett és bioturbált homokok a deltatorkolatok üledékei lehetnek. A finomhomok már messziről szállított, érett üledék, a Pannon-tavat ÉNyról feltöltő deltarendszer üledékeként értelmezhető (Újfalui Formáció). Felhalmozódási üteme gyors lehetett, az élővilágnak nem mindig volt ideje birtokba venni és átkeverni, ilyenkor megmaradt az eredeti üledékszerkezet. A sekély vizet szintén jelzik a litorális kagylófajok, a szárazföld közelségét pedig a ritkán megjelenő kvarckavicsok. A finomhomokot fedő kékes agyag megjelenéséig a legalacsonyabban elhelyezkedő, 1-2-3. sz. feltárásokban jóval vastagabb rétegsor rakódott le, mint a többi helyszínen (2. ábra), ez arra mutat, hogy a tó tagolt domborzatú területet öntött el. A kékesszürke, kőzetlisztes agyag deltasíksági öblökben rakódhatott le, a hullámbázis és viharhullámbázis között. Itt is megfigyelhetők hirtelen üledékbehordással járó események, pl. viharok nyomai az agyagba települő finomhomokréteg formájában, amelyben litorális és szublitorális kagylófajok különálló, általában domború oldalával fölfelé elhelyezkedő teknői figyelhetôk meg sûrûn egymás mellett. Ezek az üledékek a deltasíkság alsó részére jellemzőek, ahol a vízborítás állandó volt. A rétegsor felsőbb részéről a NmVIII fúrás hiányos dokumentációja miatt nem vonhatók le további, pl. a vízmélység változására vonatkozó, következtetések.

\section{Tektonikai adatok}

A vizsgált feltárásokban több tektonikai esemény nyomait sikerült megfigyelni. A 3. feltárás keresztrétegzett finomszemú homokrétegeiben fölfelé elhaló, szinszediment vetők láthatók (3. ábra, B). Ezek meredekségük, valamint az egymás mellett megfigyelhető, néhány cmes, látszólagos normál és feltolódásos elvetések jelenléte miatt alapvetôen eltolódások lehetnek.

A szerkezeti elemek egy másik csoportja az új mészkőbányában (9-10. feltárás) tárult fel. Itt számos párhuzamos, déli dőlésû vetô látható a triász mészkő meredeken dőlő réteglapjai mentén, és más irányú vetősíkok is megfigyelhetôk. A síkokon változatos irányú karcok láthatók, tehát többször reaktiválódtak; nagyobbik részük ferde vagy vízszintes. A vetők közül a legnagyobb a bánya északi részén található, $180 / 75^{\circ}$ dőlésú, és oldalirányban több mint $100 \mathrm{~m}$ hosszan követhetô (5. ábra). E sík mentén a triász mészkő észak felé a pannóniai rétegekre tolódott, a két összlet között a sík mentén $0,5-1 \mathrm{~m}$ vastagságban erôsen nyírt, világosszürke, nagy földpátszemcséket tartalmazó agyag látható. A feltolódás két oldalán, a bánya alsó és fölső szintjén azonos rétegsor, triász mészkőre települő pannóniai homok és agyag található. Ezek magasságkülönbsége alapján a függőleges elvetés mértéke 13-16 m, és biztosra vehető, hogy a vető legalább a pannóniai összlet lerakódása után (7,5 M év) aktív volt.

A vető menti agyag azonosítható LőRENTHEY (1890, 47. o.) „riolit-kaolin”-jával, illetve a HÁMOR et al. (1968, 20. o.) és HÁmoR (1970, 47. o.) által leírt, erősen mállott, alsó-miocénnek tartott riolittufával. A szénbánya vágataiban számos helyen és a felszínen is észlelték ezt a képződményt és legalább két sávban térképezték a jelenlétét, mindig vetőhöz kapcsolódva: a triász és jura összlet tektonikus érintkezése (,,pikkelyhatár") mentén több m vastagságban, valamint ettől északra, a triász karbonátokon belül. A karbonáton belüli sáv oldalirányban 1 km-nél, a triász-jura határon lévő (LőRENTHEY 1890) 1,5 km-nél nagyobb távon követhetô. A vető függôleges kiterjedése is jelentôs: a most a mészkôbányában 220-230 m tszf. magasságban észlelt becsípett riolittufát a közvetlen alatta húzódó Rezsô-táróban 157 m tszf. magasságban dokumentálták (HÁMOR et al. 1968, HÁMOR 1970). Ez legalább 80 m függóleges irányú elmozdulást jelent a riolittufa keletkezése óta. Mivel a pannóniai képződmények talpának függőleges elvetése 20 m alatti, a mozgás jelentős része a késő-miocén 


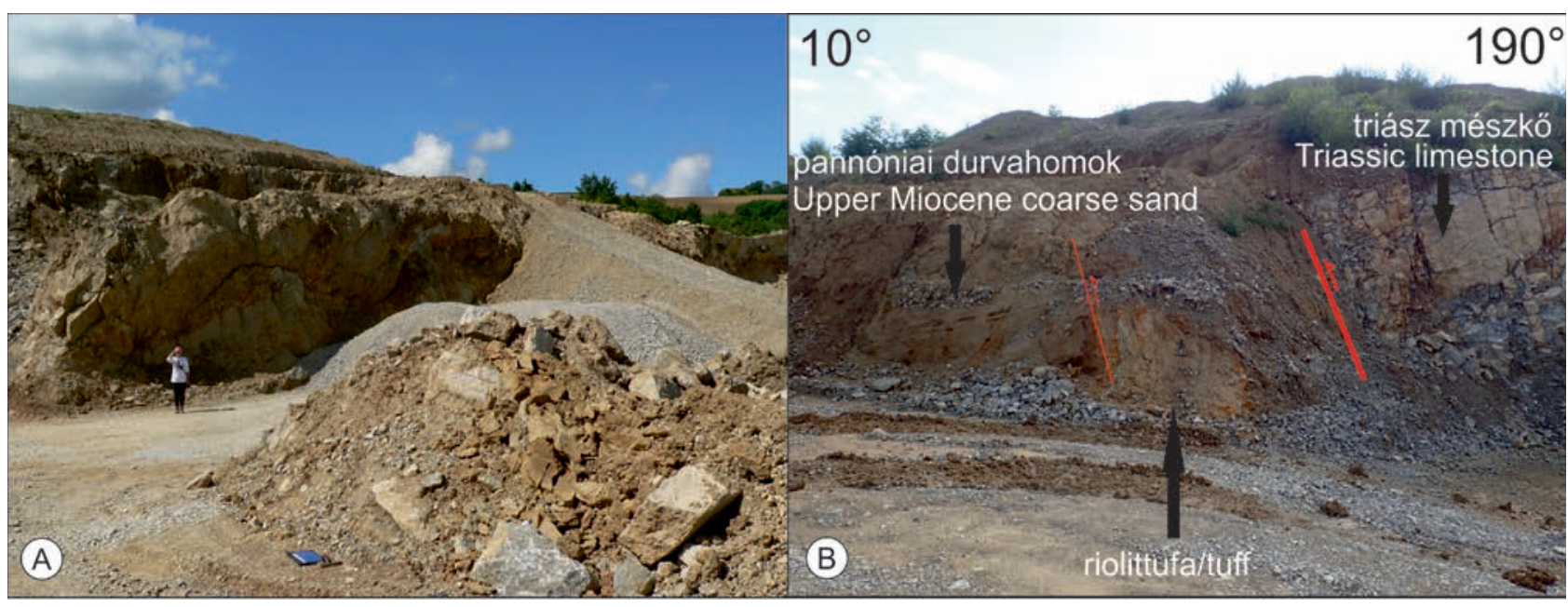

5. ábra. A feltolódás látképe ÉK-ről (A) és a kapcsolat a pannóniai durvahomokkal (B)

Figure 5. Panoramic view of the reverse fault from $N E(A)$ and the contact with the Pannonian very coarse sand $(B)$

előtt kellett hogy végbemenjen. A triász és jura képződményeket elválasztó vető dőlése csapás mentén változik — nyugatról keletre a délies $70^{\circ}$-os dőlés $65^{\circ}$-os északira vált (HÁMOR et al. 1966) —, ami az eltolódások jellemzője. Mindezen adatok fényében megállapítható, hogy egy jelentôs vetőzóna húzódik keresztuil K-Ny-ias irányban a területen, amely a kora-és/vagy középsô-miocénben feltolódásos és jelentős horizontális komponenssel múködött. Korábbi elemzések (CSONTOS et al. 2002) a kora-miocénre rekonstruálnak transzpressziót, ez alapján a Nagymányokon tapasztalt mozgások a kora-miocén végén, a tufaszórás után történhettek. A késő-miocén üledékképződés után ezek a vetôk újultak fel, ismét feltolódásos összetevôvel. Fentiek megerôsítik TARI (1992) transzpressziós modelljét az Északi-pikkely miocén-posztmiocén szerkezetalakulásáról.

A bányában feltárt feltolódásokhoz hasonló helyzetû az Északi-pikkely peremvetője, amely Nagymányoknál a falu déli részén fut keresztül (HÁMOR et al. 1966; 1. ábra). A Nagymányok K-8 és K-9 fúrások (1. ábra) közvetlen a peremvető előtt (attól északra) fúrtak 300 m pannóniai üledéket. A mészkóbánya feltárása azt mutatja, hogy a terület posztpannóniai emelkedése nem csak a peremvető mentén zajlott, hanem vele párhuzamos, kisebb vetőágak is hozzájárultak.

A harmadik jelenség a rétegek dőléséhez kapcsolódik, azok kivétel nélkül északias irányúak $5-15^{\circ}$ dôlésszöggel (1. ábra). Mivel deltaüledékek legfeljebb $5^{\circ}$ dőléssel rakódnak le (MAGYAR et al. 2013), és a rétegek dôlése között nagy eltérés nem volt, ezért ebből egy egységes posztpannóniai billenés is feltételezhetô. Ez a billenés létrejöhetett akár az előbb ismertetett feltolódásos mozgások hatására is, azaz lehet velük egykorú.

\section{Szeizmikus szelvények és fúrások}

A feltárások tágabb környezetben való elhelyezéséhez, illetve a hegységi és előtéri fejlődéstörténet összehasonlítá- sához az északi előteret ábrázoló szeizmikus szelvényeket használtuk fel. Az elérhetô szelvények közel párhuzamos lefutásúak voltak és nagyon hasonló földtani jellegeket mutatnak. Közülük a legjellemzőbbet mutatjuk be, amelynek közelében megtalálhatók voltak a szelvény értelmezéséhez felhasználható, dokumentált, akár alaphegységet ért fúrások (6. ábra).

Pannóniai üledékképződés kezdetben csak a Mecsek lábánál húzódó árokszerú medencében zajlott. A pannóniai feküt fúrások hiányában itt nem ismerjük. A Mázaszászvár K-3 fúrás alapján szürke, csillámos agyagmárgarétegek rakódtak le összesen több mint $380 \mathrm{~m}$ vastagságban. Az összletet nyílttavi képződményként értelmezhetjük és a Száki Agyagmárga Formációba soroljuk. A medence feltöltődése után a magasabban fekvő, a Györe-1 fúrás rétegsora alapján alaphegységi kôzetekből álló területek is fokozatosan víz alá kerültek. Ebben a fúrásban a pannóniai rétegsor vékony (7,2 m) kavicsos homokrétegekkel indult (KLEB 1973). A rálapolódások fölötti reflexiók már végigkövethetôk a szelvényen. A lerakódott üledék a Györe-1 megőrzött magmintái alapján viszonylag homogén, sötétszürke agyagmárga, gazdag molluszkafaunával. A fúrás idősebb szakaszában előforduló puhatestűek (így például Congeria ungulacaprae, C. zagrabiensis, Paradacna okrugici) azt mutatják, hogy a széles, alaphegységi kőzetekből álló hátság teljes elöntése a Congeria praerhomboidea biokron (sensu MAGYAR \& GEARY 2012) idején vagy az után, legkorábban 8,9 millió éve történt. A 6. ábra kék szaggatott vonala mentén sûrüsödnek a reflexiók, az Mz-3 fúrás földtani naplója és a Györe-1 maganyaga alapján e fölött agyagmárga és finomhomok rétegei váltakoznak. Ezt az összletet az Újfalui Formációba soroljuk és sekély deltaüledékként értelmezzük. A lejtóreflexiók hiányát a kis vízmélység okozhatja. Az Újfalui Formációba, azaz az alp-kárpáti hegységkeretból érkező delta üledékeihez való sorolást alátámasztják a Györe-1 nehézásvány-vizsgálatai, amelyek ebből a szakaszból alpi típusú metamorf kőzetek ásványait mutatták ki (SCHWÁB 1960). A Györe-1 fúrásban 245 m mélységben előforduló 


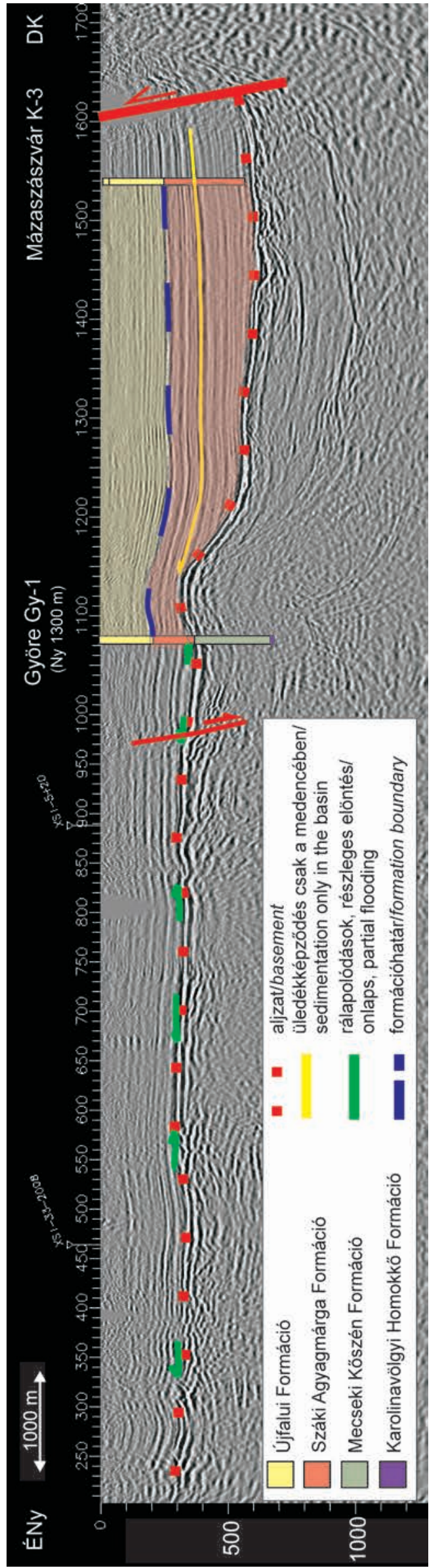

(2)
Prosodacnomya dainellii és az ugyanitt és e fölött számos helyen előforduló Prosodacnomya vutskitsi alapján (SCHWÁB 1960) a deltasíksági üledéksor lerakódása a. dainellii litorális molluszka biokron végétől, kb. 7,3 M év után történt.

A szelvény DK-i végén található vetô mentén a Mecsek alaphegységi blokkja az előtéri üledékekre tolódott. Az előtéri árokban a reflexiók vastagsága nem változik a vető felé, ez alátámasztja a feltolódás posztpannóniai voltát. A Györe-1 fúrástól északra látható vető a szelvényen megjelenő normál elvetés mellett meredeksége alapján alapvetôen eltolódásos. Ebből a vetőből csak rövid szakasz látszik egyértelmúen, a szelvény fölső részén nem látható, hogy a vetô elvégződik-e a pannóniai üledékekben. Emiatt nem állapítható meg, hogy valamikor az üledékképződés során vagy azt követően múködött, de a széthúzásos komponens miatt valószínúbb az első lehetőség.

\section{Fejlódéstörténet}

A feltárások, fúrások és szeizmikus szelvények segítségével rekonstruálható a terület késô-miocén fejlődéstörténete.

Nagymányok környékén a pannóniai üledékképződés kezdetben csak az északi előtérben indult meg: a Pannon-tó először az Északi-pikkely északi lábánál húzódó, néhány km széles árkot, majd attól északra az alig tagolt alaphegységi hátat öntötte el. Vizében nyílttavi, agyagmárgásaleuritos rétegsor rakódott le (Száki Agyagmárga). Ôslénytani vizsgálatok hiányában a transzgresszió kezdetének időpontját nem ismerjük; az árokban a nyíltvízi üledékfelhalmozódás rendszerint lassú üteme (MAGYAR et al. 2004) és az üledéksor nagy vastagsága alapján a terület akár a pannóniai korszak nagy részében víz alatt lehetett. Az ároktól északra húzódó széles hát elöntése 8,9 M év után történt.

A nyílttavi üledékképződést késôbb felváltotta az északról érkező, alp-kárpáti eredetű deltarendszer hordalékának felhalmozódása (Újfalui F.). Ez az északi előtér lapos hátán 7,3 M év körül történhetett meg. A delta érkezésének koráról a tágabb környezetben is rendelkezünk adattal. Nagymányoktól valamivel nyugatra, az Északi-pikkely közvetlen előterében, Vázsnok és Kisvaszar mellett az Újfalui Formációba sorolható rétegsorok faunája a Prosodacnomya dainellii litorális molluszkazónába tartozott (HoRvÁTH et al. 2008), tehát az összlet keletkezési ideje 7,3-7,5 millió évre tehetô. A deltarétegsorok a gyors ütemú üledékbehordás miatt egy adott helyen függőleges szelvényben gyakorlatilag — a biosztratigráfiai felbontás lehetőségeit figyelembe véve - egykorúnak vehetôk (MAGYAR 2010), így ezt a két kort a hegység közvetlen északi előterében a teljes Újfalui Formációra kiterjeszthetjük. Ez összhangban van azzal, hogy a Pannon-tó selfpereme 8 millió évvel ezelőtt a Kapostól valamivel északra helyezkedett még el (SzTANó et al. 2013, MAGYAR et al. 2013, Törő et al. 2012). A klinoformok hiánya kis vízmélységre utal, a terület sekély vízzel borított hátság lehetett (hasonlóan a Mecsek nyugati előteréhez, 1. SzTANÓ et al. 2015). 
Az Északi-pikkely alaphegységi blokkján a fiatal Pannon-tavi rétegsor közvetlenül a triász mészkőre települ, azaz a terület a pannóniai korszak korai szakaszában szárazulat volt. Itt az üledékképződés a deltarendszernek a Mecsek lábához történő érkezésével egyidőben, vagy nagyon kevéssel előtte kezdődött meg. Gyors transzgresszió hatására kezdetben a Kállai Kavics Formációba sorolható éretlen durvahomok rakódott le sekélyvízi, partközeli környezetben. Anyaga helyi lepusztulástermék, a közelben megtalálható alsó-miocén Szászvári Formációból származtatható. Ezt a törmeléket gyorsan követték a deltarendszer üledékei (Újfalui F.). A delták által kezdetben lerakott üledékekhez a környezô magasabb térszínek anyaga is keveredett. A fokozatos vízszintemelkedéssel ez egyre kevésbé jelentkezett, de a Mecsekből az itt látható pannóniai rétegsor teljes alsó szakaszának lerakódása során végig szállítódott helyi lepusztulástermék, melyet a rétegekben előforduló kavicsanyag bizonyít. Ez lehetett a kiemelt területek anyaga, vagy a korábban lerakott litorális üledékek áthalmozódása is.

A pannóniai üledékképződés során kisebb léptékú eltolódásos mozgások nyomait látjuk feltárásban, és vélhetőleg ugyanilyen korú a szeizmikus szelvényen látható normálvető is. A szeizmikus szelvényen ugyanakkor nem látszik, hogy a Mecsek északi határát alkotó fő vetőzóna aktív lett volna.

A miocén üledékképződés legvégén, vagy annak lezárulása után erôsebb tektonikai hatások érték a területet. $\mathrm{Az}$ Északi-pikkely alaphegységi tömbje az északi előtérre tolódott; a vetőzóna meredeksége alapján valószínúleg eltolódásos összetevôvel is rendelkezett. A peremvetővel közel párhuzamos sík(ok) mentén a hegység belsôbb részében is történtek hasonló jellegú, kisebb elvetést okozó mozgások. Úgy túnik, hogy a posztmiocén tektonikai események a területen alapvetően eltolódásos-feltolódásos nyírózónában mentek végbe, hasonlóan TARI (1992) modelljéhez, illetve a szomszédos Bonyhádi-medencében korábban leírtakhoz (WóRUM \& HÁMORI 2010). A feltárások rétegdőlései alapján a pannóniai rétegsor egységesen kibillent észak felé; a billenés akár az előbb felsorolt vetók aktivitásához is kapcsolódhat, időbeli viszonyuk a rendelkezésre álló adatok alapján nem tisztázható pontosan.

\section{Köszönetnyilvánítás}

Köszönettel tartozunk SzTANó Orsolyának a konzultációkért, valamint HABLY Lillának a növénymaradvány, BoSNAKOFF Mariannak pedig az otolith meghatározásáért. Hálásak vagyunk UHRIN Andrásnak és PETRIK Attilának a kézirat lektorálásáért és építő kritikáikért. A terepi munkában NAGY Gábor, JANKOVITS András és Éva Zsombor volt segítségünkre. Az I. tábla $F$ képén látható kagylót KATONA Lajos Tamás (MTM Bakonyi Természettudományi Múzeuma, Zirc) gyújtötte, és neki köszönjük a B, C, F, G, H, I képek fotóit is. Köszönjük FoDOR Károlynak (Dafotókő Kft.), hogy lehetôvé tette a mészkốbányában végzett munkát, valamint a Magyar Bányászati és Földtani Szolgálatnak, hogy engedélyezte a szeizmikus szelvény publikálását. A munkát támogatta a Nemzeti Kutatási, Fejlesztési és Innovációs Hivatal (NKFIH/OTKA) PD104937 és 116618 projektje, valamint a Bolyai János Kutatási Ösztöndíj. Ez a tanulmány az MTA-MTM-ELTE Paleontológiai Kutatócsoport 273. közleménye.

\section{Irodalom — References}

BABInSZKi E., SZTANó O. \& MAgYARI Á. 2003: Epizodikus üledékképződés a Pannon-tó Kállai-öblében: a Kállai Homok nyomfosszíliái és szedimentológiai bélyegei — Földtani Közlöny 133/3, 363-382.

BARABÁs A. 2010: A délkelet-dunántúli hidrogenetikus uránérctelepek földtani környezete és összehasonlító értékelésük. — Doktori értekezés, Pécsi Tudományegyetem, 170 p.

Boomer, I., Von Grafenstein, F. Guichard, F. \& BiedA, S. 2005: Modern and Holocene sublittoral ostracod assemblages (Crustacea) from the Caspian Sea: a unique brackish, deep-water environment. - Palaeogeography Palaeoclimatology Palaeoecology 225, 173186. https://doi.org/10.1016/j.palaeo.2004.10.023

CZICZER I. 2014: Pannóniai korú puhatestú faunák a Mórágyi-rögön és délkeleti elooterében: rétegtani, környezeti és ösföldrajzi értékelés. — Doktori értekezés, SZTE Földtani és Őslénytani Tanszék, Szeged. https://doi.org/10.14232/phd.2349

Csontos, L., Benkovics, L., Bergerat, F., MAnsy, J-L. \& Wórum, G. 2002: Tertiary deformation history from seismic section stufy and fault analysis in a former European Tethyan margin (the Mecsek-Villány area, SW Hungary). — Tectonophysics 357/1-4, 81-102. https://doi.org/10.1016/S0040-1951(02)00363-3

HÁMOR G. 1966: Újabb adatok a Mecsek hegység szerkezetföldtani felépítéséhez. — Magyar Állami Földtani Intézet Évi Jelentése az. 1964. évról, 193-206.

HÁMOR G. 1970: A kelet-mecseki miocén. — Magyar Állami Földtani Intézet Évkönyve 53/1, 1-371.

HÁMOR G., NAGY E. \& FöLDI M. 1968: Magyarázó a Mecsek hegység földtani térképéhez, 10 000-es sorozat, Nagymányok. — MÁFI kiadvány, Budapest, $40 \mathrm{p}$.

HÁMOR G., NAGY E. \& Földi M. 1972: Magyarország földtani térképe, 10 000-es sorozat, Nagymányok. — MÁFI kiadvány, Budapest. Hofman, E. A. 1966: Ekologija sovremennik i novokaspiskij ostracod Kaspiskovo morja. — Izd. Nauka, Moskva 249-294. Moskva.

Holmes, J. A. 2001: Ostracoda. — In: SMOL, J. P., BIRKS, H. J. \& LAST. H. J. (eds): Tracking environmental change using lake sediments, Vol. 4: Zoological Indicators. — Kluwer Acad. Publisher, Dordrecht, 125-151. https://doi.org/10.1007/0-306-47671-1_7 
Horváth J., CZICZER I. \& Uhrin A. 2008: Pannóniai puhatestú fauna a Vázsnoki és Kisvaszari feltárásokból. — In: HABLY L., VöRÖs A., PÁlfy J. \& Bosnakoff M. (szerk.): 11. Magyar Óslénytani Vándorgyúlés, Szögliget. Program, elóadáskivonatok, kirándulásvezetó. Magyarhoni Földtani Társulat, 14-15.

JÁMBOR Á. 1980: A Dunántúli-középhegység pannóniai képződményei. —Magyar Állami Földtani Intézet Évkönyve 62, 243 p.

JuHÁsz Gy. \& MAGYAR I 1993: A pannóniai (s.l.) litofáciesek és molluszka-biofáciesek jellemzése és korrelációja az Alföldön. Review and correlation of the Late Neogene (Pannonian s.l.) lithofacies and mollusc biofacies in the Great Plain, eastern Hungary. Földtani Közlöny 122, 167-194.

KLEB B. 1973: A mecseki pannon földtana. — Magyar Állami Földtani Intézet Évkönyve 53/3, 750-943.

KovÁcs Á. 2017: A Nagymányok környéki pannóniai üledékek vizsgálata. — OTDK dolgozat, Pécsi Tudományegyetem, 45 p.

Krstič, N. 1968: Pontian Ostracods from Eatern Serbia: Candona and Cypria. — Vesnik Zavoda za Geol i Geofiz. Izt. Series A., 26, 243251.

KrstiČ, N. 1972a: Rod Candona (Ostracoda) iz kongeriskih slojeva juznog dela pannonskog basena. — Srpska akad. nauka i um. Pos. izd., knjiga CDL. 39, 2-145. Beograd.

Krstič, N. 1972b: Ostracodi kongeriskih slojeva: X. Loxoconcha. — Bull. Mus. Hist. Nat.(A) 27, 243-258. Beograd.

LÓRENTHEY I. 1890: A nagymányoki (Tolna m.) pontusi emelet és faunája. — Magyar Királyi Földtani Intézet Évkönyve 9, 33-48.

LŐRENTHEY I. 1893: A szegszárdi, nagy-mányoki és árpádi felső-pontusi lerakodások és faunájok. — Magyar Királyi Földtani Intézet Évkönyve 10/4, Budapest.

MagYar, I. 1995: Late Miocene mollusc biostratigraphy in the eastern part of the Pannonian basin (Tiszántúl, Hungary). — Geologica Carpathica 46, 29-36.

MagYAR I. 2010: A Pannon-medence ósföldrajza és környezeti rekonstrukciója a késó miocénben. — Geolitera kiadó, Szeged, 140 p.

Magyar, I. \& GeARY, D. 2012: Biostratigraphy in a late Neogene Caspian-Type Lacustrine Basin: Lake Pannon, Hungary. — AAPG Memoir 95, 255-264.

Magyar I., JuhÁsz Gy., Szuromi-Korecz A. \& SüTő-Szentai M. 2004: A pannóniai Tótkomlósi Mészmárga Tagozat kifejlődése és kora a Battonya-pusztaföldvári-hátság környezetében. — Földtani Közlöny 134, 521-540.

Magyar, I., Radivojević, D., Sztanó O., Synak, R., Ujszászi K. \& Pócsik M. 2013: Progradation of the paleo-Danube shelf margin across the Pannonian Basin during the Late Miocene and Early Pliocene. - Global and Planetary Change 103, 168-173. https://doi.org/10.1016/j.gloplacha.2012.06.007

Ruiz, F., Gonzales-Regalado, M. L., Munoz, J. M., Pendon, J. G., Rodriguez-Ramirez, A., Cacares, L. \& Rodrigez Vidal, J. 2003 : Population age structure techniques and ostracods: applications in coastal hydrodynamics and paleoenvironmental analysis. — Palaeogeography, Palaeoclimatology, Palaeoecology 199, 51-69. https://doi.org/10.1016/S0031-0182(03)00485-1

SCHWÁB M. 1960: Györe-1. távlati kutatófúrás. — Magyar Állami Földtani Intézet Évi Jelentése 1957-58-ról, 323-335.

SEbE K., KonRÁD Gy. \& Magyar I. 2013: A legmagasabban fekvő mecseki pannon-tavi üledékek helyzete és kora. — Földtani Közlöny 143/1, 67-72.

Sebe K., Magyar I., Csillag G. \& SzTANó O. 2015: A mecseki pannóniai üledékek rétegtana: új adatok, eredmények és kérdések. — Tisia konferencia kiadványa, 72-76.

Selmeczi, I., Lantos, M., Bohn-Havas, M., Nagymarosy, A. \& Szegő, É. 2012: Correlation of bio- and magnetostratigraphy of Badenian sequences from western and northern Hungary. — Geologica Carpathica 63/3, 219-232. https://doi.org/10.2478/v10096-0120019-1

Sztanó O., Magyar I., Szónoky M., Lantos M., Müller., Lenkey L., Katona L. \& Csillag G. 2013: A Tihanyi Formáció a Balaton környékén: típusszelvény, képződési körülmények, rétegtani jellemzés. — Földtani Közlöny 143/1, 73-98.

Sztanó, O., Sebe, K., Csillag, G. \& Magyar, I. 2015: Turbidites as indicators of paleotopography, Upper Miocene Lake Pannon, Western Mecsek Mountains (Hungary). — Geologica Carpathica 66/4, 331-344. https://doi.org/10.1515/geoca-2015-0029

SZUROMINÉ KoRECZ A. 1991: A DK-dunántúli pannóniai s.l. ostracoda fauna vizsgálatának eredményei (The Pannonian s.l. ostracod fauna from SE Transdanubia — in Hungarian) — PhD thesis, Eötvös Loránd University, Department of Paleontology, Budapest, 231 p.

TARI, G. 1992: Late neogene transpression in the Northern Thrust zone, Mecsek mts., Hungary. — Eötvös University, Department of Geology, Budapest, 165-187.

TÖRŐ B., SZTANó O. \& FodOR L. 2012: Aljzatmorfológia és aktív deformáció által befolyásolt pannóniai lejtőépülés Észak-Somogyban (Inherited and syndepositional structural control on the evolution of the slope of Lake Pannon, Northern Somogy, Hungary). Földtani Közlöny 142/4, 339-356.

VADÁsz E. 1935: A Mecsekhegység. — Magyar Tájak Földtani Leírása, Magyar Királyi Földtani Intézet, Budapest, 180 p.

WeIN Gy. 1965: Az „Északi Pikkely” a Mecsek hegységben. — Bányászati Lapok 6, 402-411.

WóRUM G. \& HÁMORI Z. 2010: A BAF-kutatás szempontjából releváns, a MOL Rt. által készített archív szeizmikus szelvények újrafeldolgozása. — Kutatási jelentés (BAF10-H.1.2/1), Mecsekérc Zrt. Adattár, 83 p.

Kézirat beérkezett: 2018. 05. 31. 


\section{I. tábla - Plate I.}

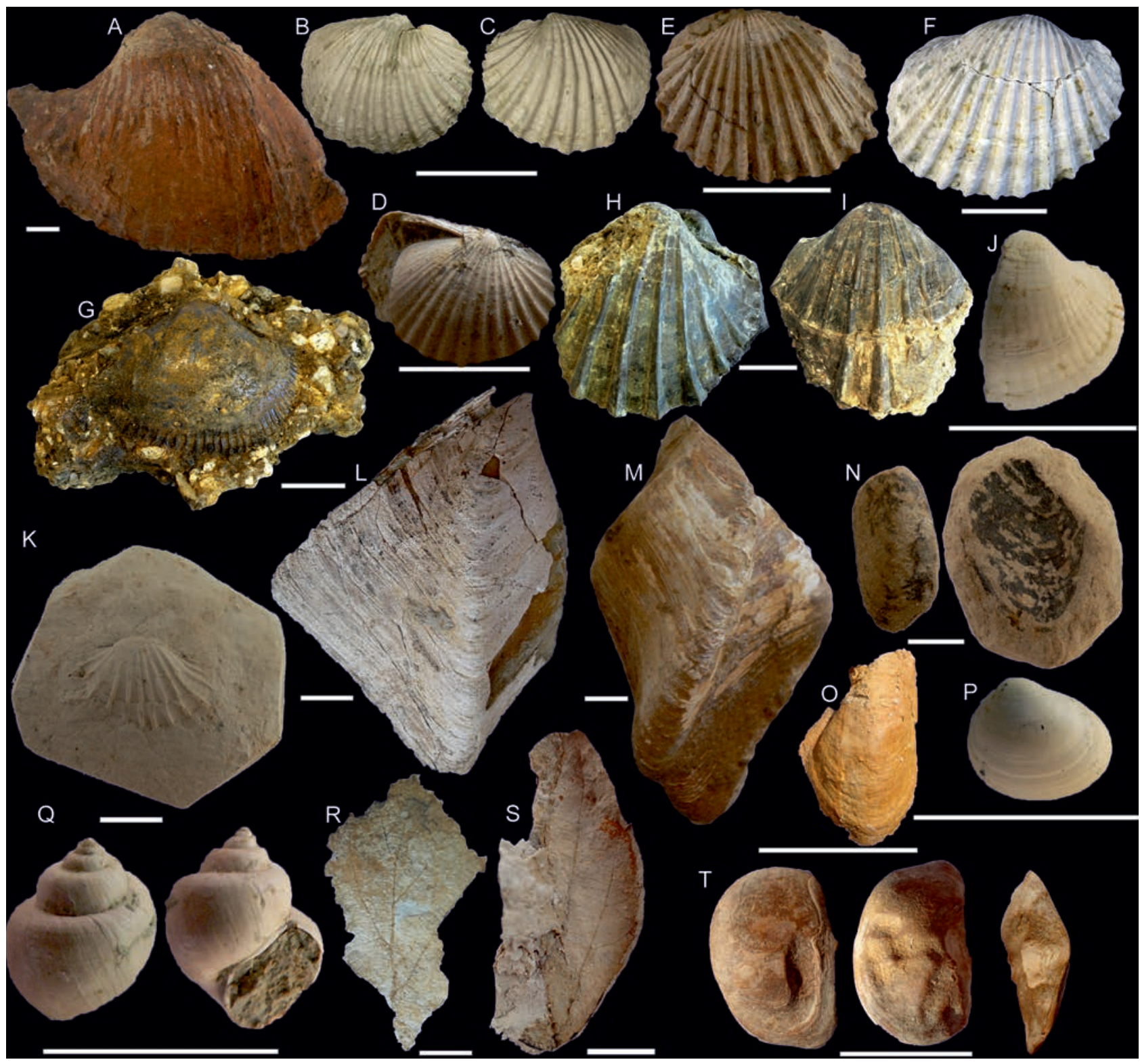

A pannóniai összlet ősmaradványai. Fossils of the Pannonian sediments.

A) Lymnocardium schmidti (3; INV 2018.183.),

B-D) L. szaboi (3; INV 2018.169-170.),

E-F) L. stevanovici (3/9; INV 2018.167/2016.8.3.),

G) L. banaticum (9; INV 2018.201.),

H-I) L. ferrugineum (9; INV 2018.198.),

J) Prosodacnomya sp. (3; INV 2018.174.),

K) Paradacna okrugici (3; INV 2018.176.),

L-M) Congeria rhomboidea (3; INV 2018.161-162.),

N) Dreissenomya intermedia (3; INV 2018.166.),

O) Dreissena auricularis (9; INV 2018.190.),

P) Pisidium sp. (3; INV 2018.178.),

Q) Zagrabica sp. (3; INV 2018.180.),

R) Alnus cecropiifolia (3; HNHM-PBO 2018.366.2.),

S) Celtis sp. (3; HNHM-PBO 2016.4.2.),

T) Umbrina cirrhosoides otolith (3; VER 2018.1893.).

Az aránymértékek mindenütt $1 \mathrm{~cm}$-nek felelnek meg, zárójelben dőlt betûvel a feltárás száma, ahonnan az ôsmaradvány előkerült és a leltári számuk. Scale: $1 \mathrm{~cm}$. 
